\title{
A Study to Compare the Clinical Profile and Laboratory Abnormalities in the Subclinical Hypothyroidism Patient with Healthy Controls
}

\author{
Dr P. S Pipliwal ${ }^{1}$ Dr Rohit Mathur ${ }^{2}$ Dr Anjana Mathur ${ }^{2}$ Dr Arvind Kumar $^{3}$ \\ ${ }^{1}$ Professor, Department Of Medicine S.P. Medical College And AG Of Hospital, Bikaner \\ ${ }^{2,}$ Post Graduate Student, S.P. Medical College And AG Of Hospital, Bikaner \\ 3. Post Graduate Student, Sms Medical College And AG Of Hospital, jaipur
}

\begin{abstract}
Background: subclinical hypothyroidism is more common than overt hypothyroidism and it is associated with Coronary artery disease and many biochemical abnormalities

Aim and objectives: A study to compare the clinical profile and laboratory abnormalities in the subclinical hypothyroidism patient with healthy controls

Methods: this is hospital based analytical study done in department of medicine at SMS medical college and AG hospital from July 2012 to June 2013. All the subjects diagnosed with elevated TSH and normal free T3 T4 TSH. Total 50 patients of subclinical hypothyroidism diagnosed as per criteria and compared with 50 healthy individuals of same age group.

Results: it was observed that cases showed significantly higher level of triglycerides and very low density lipoprotein (VLDL) levels in the patients with subclinical hypothyroidism.

Conclusion: screening of lipid profile in subclinical hypothyroidism can be helpful for preventing complication related to dyslipidemia.
\end{abstract}

\section{Introduction}

Subclinical hypothyroidism can be best defined as a high serum TSH and normal serum FT3 FT4 associated with few or no symptoms/signs of hypothyroidism. It is referred to as a state of mild thyroid failure and is essentially a laboratory diagnosis. ${ }^{1,2}$ therefore early diagnosis and treatment may prevent the onset of overt hypothyroidism and its associated effects in which include risk of coronary artery disease (CAD), peripheral vascular disease and various biochemical abnormalities.

The prevalence of subclinical hypothyroidism ranges from 4 to $15 \%$, in India there is significant numbers of patients with thyroid disease. Thyroid disease is different from other disease in terms of their ease of diagnosis, accessibility of medical treatment and relative visibility of thyroid swelling. Early diagnosis and treatment remains the cornerstone of management. ${ }^{3}$

Thyroid hormones have significant effects on the synthesis, mobilization and metabolism of lipids. They affect serum cholesterol mainly by altering lipoprotein metabolism. Hypercholestremia is favoured due to the hormone deficit and the decreased activity of the lipoprotein lipase further increases the risk of $\mathrm{CAD}^{12}$.

Similarly subclinical hypothyroidism may be associated with increased risk coronary artery disease and various biochemical abnormalities including increased LDL-C levels, increased total cholesterol and serum TG levels. ${ }^{13}$. Some case control trials had reported increased concentration of serum total cholesterol and LDL cholesterol in subjects with subclinical hypothyroidism compared to euthyroid controls ${ }^{14}$.

However the results of lipid profile alternations in subclinical hypothyroidism are controversial in different studies; some of those showing positive correlation and prompt reversal of changes following treatment ${ }^{6,7}$ and while other are refusing any correlation between the two ${ }^{8}$. So we planned study to determine lipid abnormalities in patients with subclinical hypothyroidism.

\section{Materials And Methods}

It hospital based analytical study done in department of medicine, SMS medical College, Jaipur Study period - July 32021 to June 2013

Study size- 50 patients of subclinical hypothyroidism diagnosed as per criteria. Matched with 50 healthy individuals (age and sex)

Sampling- cases of subclinical hypothyroidism attending OPD/ wards in department of medicine SMS medical college

Inclusion criteria 
Patients with elevated TSH (5.0 to 10 micro IU/ml) and normal total free T3/T4 levels

\section{Exclusion criteria}

- the patients suffering from overt hypothyroidism(TSH >10 IU/ml and/or clinical signs of hypothyroidism)

- the patients suffering from

a. end stage renal disease

b. underlying known cardiac disease

c. type $1 \$ 2$ diabetes mellitus

d. sever systemic infections

e. systemic arterial hypertension

- The patients undergoing treatment with thyroxin and anti thyroid drugs

- The patients undergoing treatment with anti lipidemic drugs

- Pregnant women and women on oral contraceptive drugs

\section{Data collection}

The information on age sex region occupation was noted on preformed Performa sheet. A informed consent was taken from all cases and controls. A complete history including complains, past history personal history drug history obstetrics and menstrual history was noted through systemic examination was done.

Blood sample was withdrawn from patients and healthy subjects after overnight fasting with dry disposable syringe and needle under aseptic conditions. All investigation done in central lab at SMS medical college. And results were compared with healthy controls of age \$ sex matched. Following investigation was done-

- Complete blood count

- Renal function test

- Liver function test

- Lipid profile

- Thyroid profile

- $\quad$ ESR PBF

Normal value for FT3 1.8 to 4.2

FT4 0.89 to 1.76

TSH 0.4 to $4.4 \mathrm{ul} / \mathrm{ml}$

\section{Statistical Analysis}

Microsoft excels and SPSS 17.0 for windows was used for data storage and analysis. Continuous variables were expressed as mean \pm standard deviation. Unpaired students to test and chi square test were used to determine statistical difference between variables. Pearson's coefficient was used to investigate the correlation between the two variables. Statistical significance was set at $\mathrm{P}$ value $\leq 0.05$.

\section{Results}

Table 1 Comparison of age and sex

\begin{tabular}{|c|c|c|c|c|c|c|}
\hline Age in year & \multicolumn{3}{|c|}{ Care } & \multicolumn{3}{c|}{ Control } \\
\hline & $\mathrm{M}$ & $\mathrm{F}$ & Total & $\mathrm{M}$ & $\mathrm{F}$ & Total \\
\hline$<40$ & $1 /(2.00)$ & $29(58.00)$ & $30(60.00)$ & $1(2.00)$ & $26(52.00)$ & $27(54.00)$ \\
\hline$>40$ & $5(10.00)$ & $15(30.00)$ & $20(40.00)$ & $5(10.00)$ & $18(36.00)$ & $23(46.00)$ \\
\hline Total & $6(12.00)$ & $44(88.00)$ & $\begin{array}{c}50 \\
(100.00)\end{array}$ & $6(12.00)$ & $44(88.00)$ & $50(100.00)$ \\
\hline
\end{tabular}

Mean + SD $($ case $)=38.46+12.34 \quad$ Mean + SD $($ Control $)=40.64+13.73$

The mean age was $38.46 \pm 12.34$ years and $40.64 \pm 13.73$ in cases and controls. This was similar to a study by Sanjoy K Bhandopadyay et al where it was 38.56 years ${ }^{15}$. Another study done by Saini, yadav et al showed 31.55 years ${ }^{11}$.

In our study $11(88 \%)$ were females in cases and 44(88) in controls, which was similar to study Sanjoy Bhandopandyay et al ${ }^{15}$ where females constitute $78 \%$ of study populations. Another study done by sing $\mathrm{K}$ ding 95 and Saini V Yadav A Arora et $\mathrm{al}^{11}$ where females was $88 \%$ and 80.22 of study population.

Table 2 Comparison of Lipid profile in cases and controls

\begin{tabular}{|c|c|c|c|c|c|c|c|}
\hline & & $\begin{array}{c}\text { Total } \\
\text { Cholesterol }\end{array}$ & & & TG & & \\
\hline & & Normal & Abnormal & Total & Normal & Abnormal & Total \\
\hline Case & No & 40 & 10 & 50 & 30 & 20 & 50 \\
\hline & $\%$ & 80 & 20 & 100 & 60 & 40 & 100 \\
\hline
\end{tabular}


A Study To Compare The Clinical Profile And Laboratory Abnormalities In The Subclinical ...

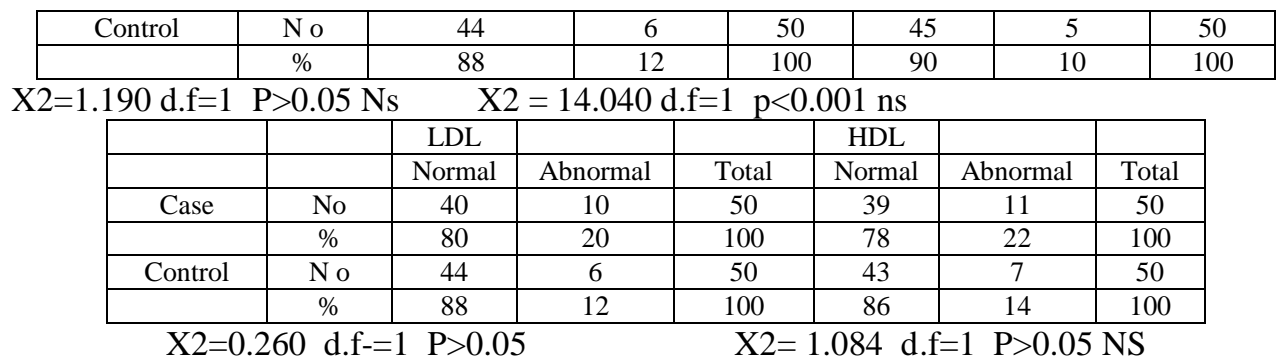

In our study out of 50 cases $10(20 \%)$ had abnormal serum TC level and out of 50 controls $5(12 \%)$ had abnormal TC level. Maximum serum TC level was $264 \mathrm{mg} / \mathrm{dl}$ and minimum serum TC was $136 \mathrm{mg} / \mathrm{dl}$ in cases, whereas in control maximum level of TC was $261 \mathrm{mg} / \mathrm{dl}$ and minimum was $261 \mathrm{mg} / \mathrm{dl}$. This difference was statistically not significant ( $\mathrm{p}>0.05)$.

These findings are similar to a study done by sing $\mathrm{K}$, sing $\mathrm{S} .{ }^{10}$. However many studies reported higher mean total cholesterol values as compared to this study. Efstathiadou et al ${ }^{12}$ and William J. Hueston ${ }^{16}$ found total cholesterol value of $222 \mathrm{mg} / \mathrm{dl}$ and $217 \mathrm{mg} / \mathrm{dl}$. Which shows statistically significant $\mathrm{p}$ value of 0.007 (p value $<0.05)$

Similarly our study showed significant difference in triglycerides level which showed maximum value of $236 \mathrm{mg} / \mathrm{dl}$ and minimum value of $124 \mathrm{mg} / \mathrm{dl}$ in cases as compared to controls where maximum value is 216 $\mathrm{mg} / \mathrm{dl}$ and minimum value $121 \mathrm{mg} / \mathrm{dl}$. ( $\mathrm{P}$ value $<0.001$ ). This study was similar to study done by William $\mathrm{J}$ Huston et al ${ }^{16}$. The LDL level in cases was maximum of $187 \mathrm{mg} / \mathrm{dl}$ and minimum of $46 \mathrm{mg} / \mathrm{dl}$, whereas in controls it was maximum of $101.5 \mathrm{mg} / \mathrm{dl}$ and $44 \mathrm{mg} / \mathrm{dl}$ which has no statistical significance with $\mathrm{p}$ value $>0.05$ similar to study done by Sing K Sing ${ }^{10}$ and William J Hueston ${ }^{16}$.

The serum HDL level in cases was maximum of $78 \mathrm{mg} / \mathrm{dl}$ and minimum of $23 \mathrm{mg} / \mathrm{dl}$ whereas in control it was maximum of $68 \mathrm{mg} / \mathrm{dl}$ and minimum of $31 \mathrm{mg} / \mathrm{dl}$. These finding is similar to study done by sing $\mathrm{K}$, Singh $\mathrm{S}^{10}$ and William J Houston ${ }^{16}$ et al which showed no statically significance. The VLDL level in cases showed maximum of $47 \mathrm{mg} / \mathrm{dl}$ and minimum of $25 \mathrm{mg} / \mathrm{dl}$ whereas in control it was $43 \mathrm{mg} / \mathrm{dl}$ of maximum and $24 \mathrm{mg} / \mathrm{dl}$ of minimum.

Table 3 Comparison of mean \pm SD in cases and controls

\begin{tabular}{|c|c|c|c|c|c|}
\hline & & \multicolumn{2}{|c|}{ Mean+Sd } & P Value & Significance \\
\hline & & Case & Control & & \\
\hline 1 & FT3 & $2.30+0.60$ & $.37+0.47$ & $>0.05$ & NS \\
\hline 2 & FT4 & $1.20+0.5$ & $1.5+0.23$ & $>0.05$ & NS \\
\hline 3 & TSH & $7.38+1.33$ & $2.52+0.8$ & $<0.001$ & HS \\
\hline 4 & TC & $181.88+35.50$ & $170.34+34.31$ & $>0.05$ & NS \\
\hline 5 & TG & $163.54+31.76$ & $143.40+19.05$ & $<0.001$ & NS \\
\hline 6 & LDL & $103.48+36.10$ & $93.12+35.59$ & $>0.05$ & NS \\
\hline 7 & HDL & $47.68+10.73$ & $48.5+8.17$ & $>0.05$ & NS \\
\hline 8 & VLDL & $32.74+6.29$ & $28.70+3.80$ & $<0.01$ & HS \\
\hline
\end{tabular}

Table 4 Mean SD of TSH in Anti TPO +ve and -ve cases group subjects

\begin{tabular}{|c|c|c|c|c|}
\hline \multirow{2}{*}{ Mean TSH } & \multicolumn{2}{|c|}{ Anti TPO } & P- VALUE & Significance \\
\cline { 2 - 3 } & $7.19 \pm 1.39$ & $7.44 \pm 1.30$ & $>0.05$ & \\
\hline
\end{tabular}

The inclusion criteria was similar to study done by Sing K, Singh ${ }^{10}$ and Saini et al ${ }^{11}$ has cut off value limit for TSH was >5.0 micro IU/ml and $6.1 \mathrm{micro} \mathrm{IU} / \mathrm{dl}$.

Mean serum T3 in case was $2.37 \pm 0.47 \mathrm{pg} / \mathrm{dl}$ and in control was $2.37 \pm 0.47 \mathrm{pg} / \mathrm{dl}$. The minimum and maximum value was $1.8 \mathrm{pg} / \mathrm{dl}$ and $3.9 \mathrm{pg} / \mathrm{dl}$ in case which was statistically not significant. Mean FT4 in case was $1.20 \pm 0.25 \mathrm{ng} / \mathrm{dl}$ and in control was $1.25 \pm 0.23 \mathrm{ng} / \mathrm{dl}$. This difference was also not statistically difference (p value >0.05). Mean serum TSH in anti TPO +ve group was $7.19 \pm 1.39 \mathrm{mg} / \mathrm{dl}$ and mean serum TSH of anti TPO - ve cases group was $7.44 \pm 1.30 \mathrm{mg} / \mathrm{dl}$. These findings were similar to study done by Salmon Rizvi et al ${ }^{17}$. The mean value of TSH in cases was $7.38 \pm 1.33 \mathrm{uIU} / \mathrm{ml}$ and in control was $2.52 \pm 0.82 \mathrm{uIU} / \mathrm{ml}$. These finding was similar to study done by Saini v et al ${ }^{10}$.

\section{Discussion And Conclusion.}

Woman in reproductive age group were most commonly affected. Our study showed significantly higher levels of triglycerides (TG) and VLDL levels in patients with sub clinical hypothyroidism. No statistical 
correlation was found between total cholesterol LDL and HDL. Our study emphasized that it is necessary that subjects with laboratory report of hypertriglyceridemia should also further examined and tested for serum thyroid hormones measurements and particularly the evaluation of TSH should be reassessed carefully.

\section{References}

[1]. Ayala A danese MD, Ladenson PW. When to treat mild hypothyroidism metabolic clin Am 2000;29:399-415

[2]. Cooper DS.Subclinical hypothyroidism. JAM Med assoc 1987;25:256-7

[3]. Unnilroshnan AG, mean UV. Throid disorders in india: an epidemiological perspective. Indian J endocr metab 2011;15:78-81.

[4]. Bhaskaran S kumar H, Nair V, Unnikrishan RV, Jayakumar C. Subclinical Hypothroidism. Indications for thyroxine therapy. Thyroid research \$ practice 2004;1:10-4

[5]. Caraccio, N Ferrannini, E Monzani, F. Lipoprotein profile in subclinical Hypothyroidism: response to levothyroxine replacement, a randomized placebo-controlled study. J clin Endocrinol metabol 2002;87(4):1533-8

[6]. Atthans BU, Staub ji, De-Lechel R.LDL/HDL changes in subclinical hypothyroidism: possible risl factor for coronary heart disease. Clin ENdocrinil 1988;28:157-63

[7]. Monazani F, Caraccio N, Kozakowa M, Dardano A, Vittone F, Virdis A, et al effect of levothyroxine replacement on lipid profile and intima media thickness hypothyroidism: a double-blind, placebo controlled study. J Clin Endocrinol Metabol 2004;89:2099106.

[8]. Danese MD, Powe NR, Sawin CT, Ladenson PW. Screening for mild thyroid failure at the periodic health examinations: a decision and ost effectiveness analysis. J Am Med Association 1996;276:285-92

[9]. Bhandopadyyy SK et al. Study of dyslipidemia in subclinical hypothyroidism. J india Med assoc 2006;104:622-6

[10]. Sing K, Singh S.alterntions in lipid fraction levels in subclinical hypothyroidism in north india population. Indian J fundamental applied life sci 2011;1(2):127-32

[11]. Saini V, Yadav A, Arora S, Singh R, Bhattacharjee J. Association between different degree of hypothyroidism and serum lipids. Internet J Med Update 2012;7(2):3-8

[12]. Efstathiadou Z, Bitsis S, Milionis HJ, Kukuvitis A, Bairaktari . Elisaf M et al. Lipid profile in subclinical hypothyroidism: is Lthyroxine substitution beneficial. Eur J Endocrinol 2001;145;705-10

[13]. Hueston WJ, Pearson WS. Subclinical hypothyroidism and the risk of hypercholesterolemia. Ann Fam Med 2004;2:351-5

[14]. Rizvi S Erica R, Victor EA et al. Subclinical hypothyroidism and deep vein thrombosis. Thrombosis haemost. 2002 may ;97(5):803-6

[15]. Bhandopadyay SK et al. Study of dyslipidemia in subclinical hypothyroidism. J Indian Med assoc 2006; 104:622-6

[16]. Hueston WJ. Pearson WS. Subclinical hypothyroidism and the risk of hyper cholesterolemia. Ann Fam Med 2004;2:351-5

[17]. Rizvi S Erica R, Victor EA et al. Subclinical hypothyroidism and deep vein thrombosis. Thrombosis Haemost. 2007 May; 97(5):803-6. 